\title{
Genetic Variation for Shelf-life of Salad-cut Lettuce in Modified-atmosphere Environments
}

\author{
Ryan J. Hayes ${ }^{1}$ and Yong-Biao Liu \\ U.S. Department of Agriculture, Agricultural Research Service, Crop Improvement and Protection \\ Unit, 1636 E. Alisal St., Salinas, CA 93905
}

\begin{abstract}
Additional IndeX words. Lactuca sativa, breeding, quality, wound induced browning, browning, minimally processed
Abstract. Packaged salad-cut lettuce (Lactuca sativa L.) for food service and salad mixes is an increasingly important component of the lettuce industry. The product is highly perishable; cold storage and modified-atmosphere (MA) packaging are used to extend its shelf life. Given the importance of this market, lettuce cultivars, breeding lines, and populations should be selected for increased shelf life in MA environments. The objectives of this research were to determine the genetic variation in lettuce for shelf life in low- $\mathrm{O}_{2} \mathrm{MA}$ environments and to develop rapid evaluation methods suitable for a lettuce breeding program. Lettuce was processed from field-grown plants of 33 romaine and three crisphead cultivars over 2 years. Shelf life was evaluated after storage in $\mathrm{MA}$ bags and in $\mathrm{CO}_{2}$-free controlledatmosphere (CA) chambers with gas ratios of $0.2 \% \mathrm{O}_{2}: 99.8 \% \mathrm{~N}_{2}, 1.0 \% \mathrm{O}_{2}: 99.0 \% \mathrm{~N}_{2}$, or $5.0 \% \mathrm{O}_{2}: 95.0 \% \mathrm{~N}_{2}$. Deteriorated leaf blade tissue was water soaked and wilted with a dull to dark or black color, and midrib tissue and heart leaves were water soaked with a translucent to dark brown color. Genetic variation for shelf life was detected using MA bags or CA chambers, and the results from both years and testing methods were significantly correlated. Oxygen concentration did not affect shelf life in the $\mathrm{CA}$ chamber experiment, which indicated that the observed symptoms in the majority of cultivars were probably not from low $\mathrm{O}_{2}$ damage or $\mathrm{CO}_{2}$ injury, although multiple mechanisms of deterioration may be involved. Selection for lettuce cultivars, breeding lines, and populations with extended shelf life is possible using MA bags or CA chamber testing methods and could facilitate a consistent release of germplasm with stable shelf life in MA environments.
\end{abstract}

Packaged salad-cut lettuce for food service and salad mixes is an increasingly important component of the lettuce industry (Glaser et al., 2001). Lettuce is highly perishable, and the cutting required in processing further shortens its shelf life (Bolin and Huxsoll, 1991). Modified-atmosphere (MA) packaging, in conjunction with temperature control, have been important techniques for extending the shelf life of these products (Kim et al., 2005; Smyth et al., 1998). Typically, low- $\mathrm{O}_{2} /$ high- $\mathrm{CO}_{2}$ environments are created that will retard oxidative browning and delay senescence (Kim et al., 2005; Smyth et al., 1998). These environments are achieved by matching product respiration with the oxygen permeability of the packaging film, and by flushing the package with a low $\mathrm{O}_{2}$ gas mixture to rapidly achieve the desired gas environment. Although this achieves control of browning, damage from $\mathrm{CO}_{2}$ injury or fermentation from low $\mathrm{O}_{2}$ stress may reduce the salability of the product (Kim et al., 2005; Smyth et al., 1998).

Shelf life and the visual quality of salad-cut lettuce can be affected by the production environment, vegetative maturity, as well as by the choice of cultivar (Chiesa et al., 2003; Couture et al., 1993; Watada and Qi, 1999). Furthermore, lettuce breeders seek to develop multiuse cultivars that are useful in a diversity of products and markets. However, little if any breeding has been reported on the shelf life of salad-cut lettuce in MA packaging. Given the importance of this market, lettuce

Received for publication 6 Aug. 2007. Accepted for publication 9 Jan. 2008. We thank Dr. Galen Peiser, Dr. Seth Goldsmith, Belinda Platts, and Randal Hauptmann for their advice with this research.

This research was supported by the California Lettuce Research Board.

The mention of a trade name, proprietary product, or vendor does not constitute an endorsement, guarantee, or warranty by the United States Department of Agriculture and does not imply its approval or the exclusion of these or other products that may be suitable.

${ }^{1}$ Corresponding author. E-mail: rhayes@pw.ars.usda.gov. cultivars, breeding lines, and populations should be selected with increased shelf life in low- $\mathrm{O}_{2} /$ high- $\mathrm{CO}_{2} \mathrm{MA}$ environments. To implement this practice, effective evaluation methods and knowledge of the genetic variation within lettuce for shelf life are needed. The objectives of this research were to determine the genetic variation for shelf life of salad-cut lettuce in low- $\mathrm{O}_{2} \mathrm{MA}$ environments and to develop rapid evaluation methods suitable for a lettuce breeding program.

\section{Materials and Methods}

LeTtuce FIELD PRoduction. Thirty-six lettuce cultivars were field grown in a randomized complete block design with three blocks over the 2005 and 2006 field seasons at the U.S. Department of Agriculture (USDA), U.S. Agricultural Research Station in Salinas, California. Twenty-nine romaine cultivars were tested in 2005 and were seeded on 26 Apr. and harvested on 5 July. In 2006, 23 romaine cultivars were tested again, along with four romaine and three crisphead cultivars that were not tested in 2005 . The 2006 experiment was seeded on $15 \mathrm{Feb}$. and harvested on 2 June. In both years, the crop was grown using standard lettuce production conditions for coastal California. To estimate maturity, the number of days to first flower was recorded for each cultivar in 2005.

MA PACKAGE EXPERIMENTS. Lettuces from the 2005 and 2006 field experiments were processed in a laboratory located at the USDA, U.S. Agricultural Research Station, Salinas, California. Three heads per replication were harvested, trimmed to commercial standards, and then stored at $1.5^{\circ} \mathrm{C}$ for at least $1 \mathrm{~d}$ before processing in 2005 and for $3 \mathrm{~d}$ before processing in 2006. One head of lettuce was used to make one bag of salad-cut lettuce. The cores were removed, and the leaves were cut into $2.5 \mathrm{~cm}^{2}$ lettuce pieces with an Easy 
LettuceKutter (NEMCO, Hicksville, OH), washed in 0.0016 $\mathrm{mol} \cdot \mathrm{L}^{-1} \mathrm{NaOCL}$ for $2 \mathrm{~min}$, and dried with a food processing centrifuge (FP-35; Bock Engineered Products, Toledo, $\mathrm{OH}$ ) at $2 g_{\mathrm{n}}$ for $5 \mathrm{~min}$. The lettuce pieces from each head were thoroughly mixed and $340 \mathrm{~g}$ of tissue was placed in transparent $22.8 \times 30.5-\mathrm{cm}$ bags made from $63.5-\mu \mathrm{m}$-thick polyethylene coextruded film with an oxygen transmission rating of $0.94 \mathrm{nmol} \cdot \mathrm{s}^{-1} \cdot \mathrm{m}^{-2} \cdot \mathrm{Pa}^{-1}$ (as determined by the manufacturer; Printpack, Atlanta, GA). Each bag containing lettuce pieces was triple flushed with $\mathrm{N}_{2}$ gas to retard oxidative discoloration by rapidly reducing $\mathrm{O}_{2}$ concentrations. $\mathrm{CO}_{2}$ was allowed to increase passively. The gas composition of the MA bags was not measured immediately after packaging, but measurements taken the day before evaluating deterioration were $\approx 0.2 \% \mathrm{O}_{2}$ and $11 \% \mathrm{CO}_{2}$. Each bag with lettuce tissue was double-sealed with a heat sealer, and randomly selected bags were submerged in water to control for air leaks. Each lettuce head was processed in random order, and all heads were processed into MA bags by $3 \mathrm{~d}$ after harvest and were subsequently placed in $1.5^{\circ} \mathrm{C}$ storage. Evaluations were conducted when some bags demonstrated $100 \%$ deterioration. This was $35 \mathrm{~d}$ after packaging in 2005 and $22 \mathrm{~d}$ after packaging in 2006. To evaluate the degree of deterioration, bags of lettuce pieces were mixed and a 120-g aliquot of lettuce pieces was taken from each bag; deteriorated pieces were collected and weighed in grams. Oxidative discoloration was only rarely observed, and was presumed to be caused by bags that were not properly sealed. Consequently, pieces with oxidative browning were not considered in this evaluation.

Controlled-ATMOSPHERE (CA) CHAMber EXPERIMENTS. Tissue processed from each head of the 2006 field trial was used to fill three $100 \times 15-\mathrm{mm}$ petri dishes; and each petri dish was randomly assigned to one of three sealed and air-tight 90-L CA chambers having a continuous supply of gas in ratios of $0.2 \% \mathrm{O}_{2}: 99.8 \% \mathrm{~N}_{2}, 1.0 \% \mathrm{O}_{2}: 99.0 \% \mathrm{~N}_{2}$, or $5.0 \% \mathrm{O}_{2}: 95.0 \% \mathrm{~N}_{2}$. The gas mixture was bubbled through water in a large jar to maintain close to $100 \%$ relative humidity. The flow rate of the gas mixture into and out of each chamber was $3 \mathrm{~L} \cdot \mathrm{min}^{-1}$, resulting in the replacement of the atmosphere in each chamber in less than $30 \mathrm{~min}$. The CA chambers containing the petri dishes were held at $2{ }^{\circ} \mathrm{C}$ for $15 \mathrm{~d}$, and were then evaluated by giving each plate a semiquantitative score for shelf life, where $0=$ no deteriorated tissue and $5=$ severe deterioration. Healthy tissue was separated from deteriorated tissue, and the proportion of deteriorated tissue was determined by dividing the weight of deteriorated tissue by the total tissue weight. Samples were exposed to air at room temperature during sample preparation. Consequently, oxidative discoloration was prevalent in this experiment. However, because our objectives were to evaluate shelf life in environments designed to retard oxidative discoloration, we did not consider this damage in our evaluations.

Data AnAlysis. The data were analyzed using Proc Mixed from SAS (version 9.1; SAS Institute, Cary, NC). The model for the MA bag experiments used cultivar, year, and cultivar $\times$ year as fixed effects and block (year) and cultivar $\times$ block (year) as a random effect. For the CA chamber experiment, data were analyzed using cultivar, $\mathrm{O}_{2}$ concentration, and cultivar $\times \mathrm{O}_{2}$ concentration as fixed effects; block, block $\times \mathrm{O}_{2}$ concentration, block $\times$ cultivar, and block $\times \mathrm{O}_{2}$ concentration $\times$ cultivar were treated as random effects. In both experiments, least square means and 95\% confidence intervals using the Tukey adjustment for multiple comparisons were generated for detection of statistical differences. For data expressed as proportions, the arcsine transformation was applied before analysis. The results were then back transformed for reporting on tables as the shelf life weight rating. Proc corr was used to calculate Pearson's correlation coefficient between the 2005 and 2006 MA bag tests, days to first flower, shelf life weight rating, and shelf life score.

\section{Results}

MA BAG EXPERIMENTS. Variation for shelf life was found and included samples with no or minimal amounts of deterioration (Fig. 1A), intermediate amounts of deterioration (Fig. 1B), and samples where every piece was deteriorated (Fig. 1C). The symptoms observed in these experiments was dependant on the tissue sampled. Damaged leaf blade tissue was water soaked and wilted, with a dull to dark or black color (Fig. 1, A and B). Midrib tissue and heart leaves were water soaked with a translucent to dark brown color (Fig. 1, A and B). The genetic variation among cultivars for shelf life was significant in 2005 and 2006 ( $P<0.0001$; Table 1). In 2005, 'Alpi' and 'Dark Green Romaine' had the most deteriorated tissue (over $100 \mathrm{~g}$ from a 120-g sample; Table 1). Twenty cultivars had significantly less deteriorated tissue than these susceptible cultivars. The extent of damage was greater in 2006, and the grand mean ( $\mathrm{t}=13.2, P<0.0001)$ was significantly higher than in 2005 . 'Alpi' and 'Dark Green Romaine' again had greater than $100 \mathrm{~g}$ of deteriorated tissue in 2006, as did 'Signal' (106.7 g), 'La Brillante' (120.0 g), and 'Triple Threat' (120 g). Twelve cultivars had significantly less deteriorated tissue than these susceptible cultivars (Table 1$)$. The genotype $\times$ year interaction was not significant $(P=0.30)$, and the data from 2005 and 2006 were significantly correlated $(\mathrm{r}=0.68 ; P=0.0004)$. Consequently, least square means were calculated for each cultivar that was evaluated in 2005 and 2006. The cultivars with the greatest amount of deteriorated tissue were Rueben's Red (71.9 g), Queen of Hearts (73.8 g), Alpi (115.5 g), and Dark Green Romaine (119.2 g). These four cultivars had significantly more damage than the five best performing cultivars, including Green Forest (19.7 g), Clemente (26.0 g), Hearts Delight (27.5 g), Darkland (27.7 g), and Green Towers (27.0 g). These results indicate that this population of romaine and crisphead cultivars has genetic variation for shelf life in MA packages.

CA CHAMBER EXPERIMENTS. In the CA chamber experiments, symptoms identical to those in the MA bags were observed. The shelf life weight rating increased from 0.06 at $5.0 \% \mathrm{O}_{2}$ to 0.15 at $0.2 \% \mathrm{O}_{2}$ (Table 2). Although more deteriorated lettuce was observed at lower $\mathrm{O}_{2}$, the difference was not significant. The shelf life score was identical for all treatments (Table 2). The data indicate that the removal of $\mathrm{CO}_{2}$ with $\mathrm{O}_{2}$ concentrations between $0.2 \%$ and $5 \%$ does not affect the defects we have measured.

Comparisons between cultivars revealed genetic variation that was significant for shelf life weight rating $(P<0.0001)$ and shelf life score $(P<0.0001)$ in the CA chamber experiments. Because the interaction between $\mathrm{O}_{2}$ concentration and genotype was not significant for shelf life weight rating $(P=0.83)$ or shelf life score $(P=0.99)$, least square means were calculated using the shelf life weight rating and shelf life score data from all three $\mathrm{O}_{2}$ treatments. 'Signal' and 'Dark Green Romaine' had the greatest amount of damage, with shelf life weight ratings of 0.31 ('Signal') and 0.42 ('Dark Green Romaine'; Table 3). 

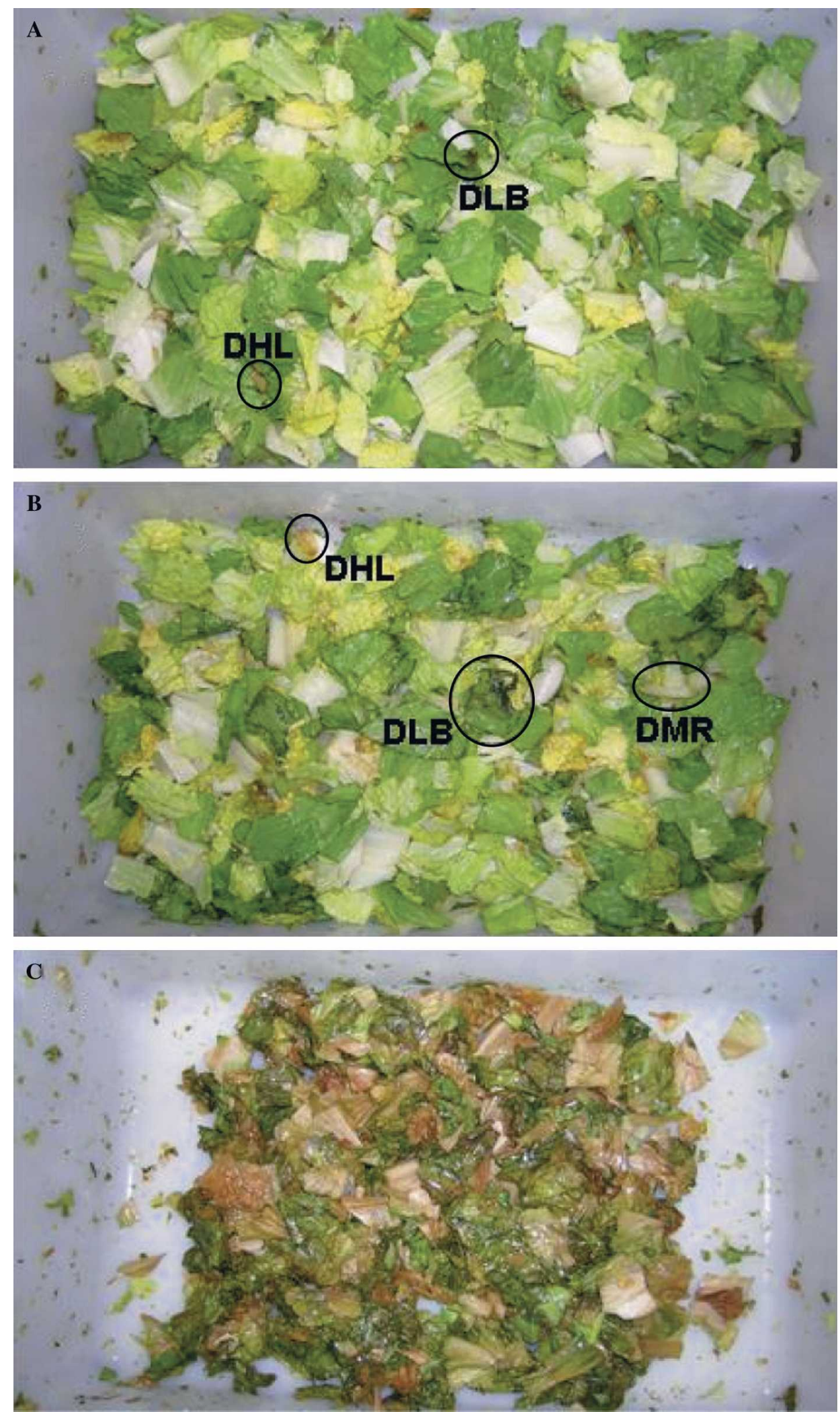

Fig. 1. Variation for shelf life in three lettuce cultivars. (A) 'Siskyou' with $3.4 \mathrm{~g}$ of deteriorated lettuce pieces. (B) 'Green Towers' with $76.8 \mathrm{~g}$ of deteriorated lettuce pieces. (C) 'La Brillante' with $120 \mathrm{~g}$ of deteriorated lettuce pieces DLB $=$ deteriorated leaf blade, $\mathrm{DHL}=$ deteriorated heart leaf, DMR $=$ deteriorated midrib.
These cultivars had significantly more damage than three other cultivars (Table 3). The shelf life score of 'Signal' and 'Dark Green Romaine' were 2.4 and 2.8 , respectively, significantly worse than 13 other cultivars. The correlation between shelf life weight rating and shelf life score was highly significant $(\mathrm{r}=0.91 ; P<$ 0.0001).

The results from the CA chamber experiments were indicative of the results from the MA bags. Significant correlations were observed between the 2005 MA bag experiments and shelf life weight rating $(\mathrm{r}=0.69 ; P=0.003)$ and shelf life score $(\mathrm{r}=0.62 ; P=0.0005)$, as well as between the 2006 MA bag experiments and shelf life weight rating $(\mathrm{r}=0.43 ; P=0.03)$ and shelf life score $(\mathrm{r}=0.42 ; P=0.02)$. Furthermore, cultivars with low amounts of deteriorated tissue in the MA bag experiments were confirmed as being resistant to these defects in the CA chamber experiments. Among these include 'Green Forest' (shelf life weight rating $=0.01$, shelf life score $=0.5$ ), 'Darkland' (shelf life weight rating $=0.02$, shelf life score $=0.2$ ), and 'Clemente' (shelf life weight rating $=0.06$, shelf life score $=0.7)$. Two cultivars did not have consistent performance between the CA chamber and MA bags. 'Triple Threat' and 'La Brillante' had complete failure ( $120 \mathrm{~g}$ of deteriorated tissue out of a $12 \mathrm{-g}$ sample) in the 2006 MA bag test, but performed better relative to the other susceptible cultivars (Dark Green Romaine and Alpi) in the CA chamber tests.

Association between maturity AND SHELF LIFE. Days to flower was measured in the 2005 season to estimate each cultivar's maturity and ranged from $86 \mathrm{~d}$ (Lital) to $122 \mathrm{~d}$ (Rueben's Red, Siskyou, Sunbelt, and Triton). Days to flower was not correlated with the 2005 MA bag experiments $(\mathrm{r}=-0.19 ; P=0.41)$, the 2006 MA bag experiments $(\mathrm{r}=0.31 ; P=0.12)$, shelf life score ( $\mathrm{r}=-0.07 ; P=0.76$ ), or shelf life weight rating $(\mathrm{r}=-0.06 ; P=0.78)$. This indicates that in this population, reproductive maturity is not related to shelf life of salad-cut lettuce stored in low-oxygen MA environments. 
Table 1. The mean weight of deteriorated leaf tissue in 36 lettuce cultivars stored at $1.5^{\circ} \mathrm{C}$ in three MA bags made from each of three field replications grown in 2005 and 2006 at Salinas, California.

\begin{tabular}{|c|c|c|c|c|}
\hline \multirow[b]{3}{*}{ Cultivar } & \multicolumn{4}{|c|}{ Mean wt of deteriorated tissue $(\mathrm{g})$} \\
\hline & \multicolumn{2}{|c|}{2005} & \multicolumn{2}{|c|}{2006} \\
\hline & Mean $^{z}$ & SE & Mean & SE \\
\hline Barcarole & $2.5 \mathrm{abc}$ & 22.5 & 55.4 abcd & 13.0 \\
\hline Clemente & $4.7 \mathrm{ab}$ & 14.0 & $47.3 \mathrm{abcd}$ & 11.9 \\
\hline Siskyou & $4.9 \mathrm{a}$ & 13.5 & 90.9 def & 13.0 \\
\hline Green Forest & $5.0 \mathrm{abc}$ & 22.5 & $34.5 \mathrm{ab}$ & 13.5 \\
\hline PIC 454 & $9.1 \mathrm{abc}$ & 16.9 & 69.3 abcde & 13.0 \\
\hline Green Towers & $9.3 \mathrm{ab}$ & 14.0 & $44.7 \mathrm{abcd}$ & 12.3 \\
\hline Brave Heart & $9.5 \mathrm{ab}$ & 14.0 & 64.6 abcde & 13.0 \\
\hline Conquistador & $12.1 \mathrm{ab}$ & 13.5 & 63.1 abcde & 13.0 \\
\hline Valmaine & $13.6 \mathrm{abc}$ & 14.6 & 61.0 abcde & 13.0 \\
\hline Darkland & $16.2 \mathrm{abc}$ & 14.0 & $39.2 \mathrm{abc}$ & 13.0 \\
\hline PIC & $16.2 \mathrm{abc}$ & 14.9 & 66.0 abcde & 13.0 \\
\hline Avalanche & $17.6 \mathrm{abc}$ & 13.5 & $41.3 \mathrm{abcd}$ & 13.0 \\
\hline Caesar & $17.8 \mathrm{abc}$ & 15.6 & 54.2 abcde & 16.8 \\
\hline Beretta & $18.3 \mathrm{abc}$ & 18.4 & & \\
\hline Gladiator & $20.6 \mathrm{abc}$ & 13.5 & 63.3 abcde & 13.0 \\
\hline Sunbelt & $21.0 \mathrm{abc}$ & 13.0 & 84.6 cdef & 13.5 \\
\hline Fresh Heart & $22.7 \mathrm{abc}$ & 15.6 & $49.1 \mathrm{abcd}$ & 13.0 \\
\hline Triton & $23.0 \mathrm{abc}$ & 16.9 & 58.6 abcde & 13.0 \\
\hline Signal & $23.1 \mathrm{abc}$ & 14.3 & 106.7 ef & 11.9 \\
\hline Heart's Delight & $23.9 \mathrm{abc}$ & 14.0 & $31.1 \mathrm{ab}$ & 13.0 \\
\hline Lobjoits & $27.6 \mathrm{abcd}$ & 17.9 & & \\
\hline King Henry & 31.3 abcde & 18.6 & 80.6 bcde & 13.0 \\
\hline Gorilla & 44.0 abcde & 14.9 & 60.9 abcde & 13.0 \\
\hline PIC 714 & 49.5 abcde & 25.3 & 61.0 abcde & 13.0 \\
\hline Rueben's Red & 56.1 abcde & 17.9 & $87.8 \mathrm{cdef}$ & 12.3 \\
\hline Lital & 64.2 abcde & 15.6 & & \\
\hline Queen of Hearts & 70.2 bcde & 22.5 & 77.4 abcdef & 15.9 \\
\hline Alpi & 110.9 de & 25.3 & $120.0 \mathrm{f}$ & 14.6 \\
\hline Dark Green Romaine & $118.4 \mathrm{de}$ & 25.3 & $120.0 \mathrm{f}$ & 11.9 \\
\hline Citori & & & $50.6 \mathrm{abcd}$ & 15.9 \\
\hline La Brillante & & & $120.0 \mathrm{f}$ & 11.9 \\
\hline Medallion & & & $49.3 \mathrm{abcd}$ & 13.0 \\
\hline Pacific & & & $21.5 \mathrm{a}$ & 13.0 \\
\hline Rubicon & & & 62.2 abcdef & 22.5 \\
\hline Salinas 88 & & & $52.3 \mathrm{abcd}$ & 11.9 \\
\hline Triple Threat & & & $120.0 \mathrm{f}$ & 15.9 \\
\hline
\end{tabular}

${ }^{\mathrm{z}}$ Means followed by different letters are significantly different at $P<0.05$. These comparisons were conducted separately for 2005 and 2006.

\section{Discussion}

Cultivars with high quality in MA packages are needed for the lettuce industry. The results presented here indicate that a population of romaine and crisphead cultivars has genetic variation for shelf life of salad-cut lettuce pieces stored in MA packages. Therefore, breeding lettuce with increased shelf life is possible. In this regard, the cultivars Clemente, Darkland, and Green Forest performed consistently well, ranking in the top 10 in every experiment we conducted. 'Alpi', 'Dark Green Romaine', and 'Queen of Hearts' clearly have an unstable shelf life and are useful susceptible controls for future experiments.

Although an increasing diversity of lettuce types are being grown, romaine and crisphead types are the most widely produced for salad-cut products. Lopez-Galvez et al. (1996) reported that romaine lettuce benefited less from MA packing than crisphead. Furthermore, industry experience indicates that romaine lettuce is more sensitive to MA than iceberg (G. Pieser, pers. comm.). The cultivars that performed well in our MA environments will likely be useful as parents in breeding programs to develop new romaine cultivars with an acceptable shelf life. It is also clear that not all crisphead cultivars have good shelf life. Wide variation was observed between the crisphead cultivars Pacific, Salinas 88, and La Brillante. Although 'La Brillante' is not a modern crisphead type cultivar, it is an important parent for disease resistance breeding (Hayes et al., 2007), and highlights the need to understand the variation for shelf life within a breeding population. The use of lines with a poor shelf life as parents, such as 'La Brillante,' warrants the rigorous testing of their resulting progeny lines.

Harvest maturity, age of tissue, and harvest date are factors that may affect the visual quality of salad-cut lettuce (Chiesa et al., 2003; Couture et al., 1993; Watada and Qi, 1999). Our results indicated that the $2006 \mathrm{MA}$ bag experiment had more damage than the 2005 experiment. In the 2006 experiment, $44 \mathrm{~d}$ more were needed to reach vegetative maturity than in 2005, and it is possible that the older age of the 2006 grown lettuce contributed to a shorter shelf life. The shorter shelf life of the 2006 experiment also resulted in the evaluation of these samples $13 \mathrm{~d}$ sooner than in the 2005 experiment because the time points to evaluate deterioration were chosen based on the occurrence of bags with $100 \%$ damage. A fixed time point for evaluation could be selected, but this may reduce a breeder's ability to detect genetic differences when production environments result in extremely low or high rates of deterioration. Selection of time points based on complete deterioration in known susceptible cultivars, such as those reported here, can be used to diminish the additive environmental variation (i.e., scaling effects) resulting from experiments conducted in diverse environments.

We demonstrated that days to flower was not correlated with visual quality of salad-cut lettuce in a genetically variable population. This strongly suggests that selection for a delay in reproductive maturity may not be an effective strategy in improving the shelf life of salad-cut lettuce. Harvest maturity and reproductive maturity may not be closely related. Harvest maturity results from the production of sufficient biomass and the formation of specific vegetative morphological features to create a harvestable head, and these events may be independent of the developmental changes leading to reproductive growth and maturity. Consequently, this may explain the lack of a relationship between days to flower and shelf life, whereas relationships between harvest maturity and shelf life have been reported by several authors (Chiesa et al., 2003; Couture et al., 1993; Watada and Qi, 1999).

The primary defects reported to occur in salad-cut lettuce packaged under low- $\mathrm{O}_{2} /$ high- $\mathrm{CO}_{2} \mathrm{MA}$ conditions are $\mathrm{CO}_{2}$ injury and fermentation (Kim et al., 2005; Mateos et al., 1993). For example, Varoquaux et al. (1996) described the butterhead cultivar Ritmo as sensitive to $\mathrm{CO}_{2}$ in MA packages. 'Ritmo' had high rates of respiration and accumulated higher levels of $\mathrm{CO}_{2}$ than two other cultivars. As a result, 'Ritmo' had increased $\mathrm{K}^{+}$leakage and brown stain $\left(\mathrm{CO}_{2}\right.$ injury). We demonstrated that symptoms of wilted, water-soaked tissue that was dull, dark, or translucent in color was unaffected by atmospheres with $0.2 \%, 1.0 \%$, or $5.0 \% \mathrm{O}_{2}$ in the absence of $\mathrm{CO}_{2}$. This 
Table 2. Mean and $95 \%$ confidence intervals of shelf life score and shelf life weight rating for 31 lettuce cultivars grown in a 2006 field experiment with three replications at Salinas, California, stored at $0.2 \%, 1.0 \%$, and $5.0 \% \mathrm{O}_{2}$ atmospheres.

\begin{tabular}{|c|c|c|c|c|c|c|}
\hline \multirow[b]{3}{*}{ Percent $\mathrm{O}_{2}$} & \multicolumn{3}{|c|}{ Shelf life wt rating ${ }^{z}$} & \multicolumn{3}{|c|}{ Shelf life score ${ }^{y}$} \\
\hline & \multirow[b]{2}{*}{ Mean } & \multicolumn{2}{|c|}{ 95\% confidence interval } & \multirow[b]{2}{*}{ Mean } & \multicolumn{2}{|c|}{$95 \%$ confidence interval } \\
\hline & & Lower & Upper & & Lower & Upper \\
\hline 0.2 & 0.15 & 0.04 & 0.31 & 1.1 & 0.7 & 1.5 \\
\hline 1.0 & 0.10 & 0.02 & 0.24 & 1.1 & 0.7 & 1.5 \\
\hline 5.0 & 0.06 & 0.00 & 0.19 & 1.1 & 0.7 & 1.5 \\
\hline
\end{tabular}

${ }^{\mathrm{z}}$ Back-transformed values from arcsine of the proportion of deteriorated tissue by weight. ${ }^{y}$ Rated based on the 0 to 5 scale where $0=$ no deteriorated pieces and $5=$ severely deteriorated pieces.

Table 3. Mean and SE of shelf life weight rating and shelf life score for 31 lettuce cultivars pooled from MA storage of $0.2 \%, 1.0 \%$, and $5.0 \% \mathrm{O}_{2}$ atmospheres.

\begin{tabular}{|c|c|c|c|c|}
\hline \multirow[b]{2}{*}{ Cultivar } & \multicolumn{2}{|c|}{ Shelf life wt rating ${ }^{z}$} & \multicolumn{2}{|c|}{ Shelf life score ${ }^{y}$} \\
\hline & Mean $^{x}$ & SE & Mean & SE \\
\hline Green Forest & $0.01 \mathrm{a}$ & 0.13 & $0.5 \mathrm{abc}$ & 0.36 \\
\hline Darkland & $0.02 \mathrm{a}$ & 0.13 & $0.2 \mathrm{a}$ & 0.37 \\
\hline Sunbelt & $0.04 \mathrm{abc}$ & 0.13 & $0.2 \mathrm{a}$ & 0.36 \\
\hline Conquistador & $0.04 \mathrm{ab}$ & 0.13 & $0.7 \mathrm{abc}$ & 0.37 \\
\hline Avalanche & $0.05 \mathrm{abc}$ & 0.13 & $0.3 \mathrm{ab}$ & 0.37 \\
\hline PIC714 & $0.05 \mathrm{abc}$ & 0.13 & $0.7 \mathrm{abc}$ & 0.36 \\
\hline Fresh Heart & $0.05 \mathrm{abc}$ & 0.13 & $0.7 \mathrm{abc}$ & 0.37 \\
\hline Gorilla & $0.05 \mathrm{abc}$ & 0.15 & $1.1 \mathrm{abcd}$ & 0.39 \\
\hline Valmaine & $0.05 \mathrm{abc}$ & 0.13 & $1.2 \mathrm{abcd}$ & 0.37 \\
\hline Gladiator & $0.06 \mathrm{abc}$ & 0.13 & $0.6 \mathrm{abc}$ & 0.36 \\
\hline Clemente & $0.06 \mathrm{abc}$ & 0.12 & $0.7 \mathrm{abc}$ & 0.35 \\
\hline Siskyou & $0.06 \mathrm{abc}$ & 0.13 & $0.9 \mathrm{abc}$ & 0.37 \\
\hline La Brillante & $0.06 \mathrm{abc}$ & 0.11 & $0.9 \mathrm{abc}$ & 0.34 \\
\hline Brave Heart & $0.06 \mathrm{abc}$ & 0.14 & $1.0 \mathrm{abcd}$ & 0.38 \\
\hline King Henry & $0.06 \mathrm{abc}$ & 0.14 & $1.0 \mathrm{abcd}$ & 0.38 \\
\hline Citori & $0.07 \mathrm{abc}$ & 0.17 & $0.7 \mathrm{abc}$ & 0.42 \\
\hline Green Towers & $0.08 \mathrm{abc}$ & 0.12 & $0.8 \mathrm{abc}$ & 0.36 \\
\hline PIC454 & $0.08 \mathrm{abc}$ & 0.13 & $1.0 \mathrm{abcd}$ & 0.36 \\
\hline Triple Threat & $0.09 \mathrm{abcd}$ & 0.20 & $0.9 \mathrm{abcd}$ & 0.46 \\
\hline Heart's Delight & $0.10 \mathrm{abcd}$ & 0.12 & $1.1 \mathrm{abcd}$ & 0.36 \\
\hline Rueben's Red & $0.10 \mathrm{abcd}$ & 0.12 & 1.5 abcde & 0.36 \\
\hline PIC & $0.12 \mathrm{abcd}$ & 0.13 & $1.2 \mathrm{abcd}$ & 0.36 \\
\hline Medallion & $0.14 \mathrm{abcd}$ & 0.13 & $1.1 \mathrm{abcd}$ & 0.37 \\
\hline Pacific & $0.17 \mathrm{abcd}$ & 0.13 & $1.3 \mathrm{abcd}$ & 0.37 \\
\hline Lobjoits & $0.21 \mathrm{abcd}$ & 0.12 & 1.7 bcde & 0.36 \\
\hline Barcarole & $0.22 \mathrm{abcd}$ & 0.14 & 1.4 abcde & 0.38 \\
\hline Queen of Hearts & $0.23 \mathrm{abcd}$ & 0.18 & 1.8 abcde & 0.44 \\
\hline Alpi & $0.24 \mathrm{abcd}$ & 0.24 & 1.4 abcde & 0.51 \\
\hline Salinas 88 & $0.27 \mathrm{bcd}$ & 0.12 & $1.8 \mathrm{cde}$ & 0.36 \\
\hline Signal & $0.31 \mathrm{~cd}$ & 0.13 & $2.4 \mathrm{de}$ & 0.36 \\
\hline Dark Green Romaine & $0.42 \mathrm{~d}$ & 0.12 & $2.8 \mathrm{e}$ & 0.35 \\
\hline
\end{tabular}

${ }^{\mathrm{z} B a c k}$ transformed values from arcsine of the proportion of deteriorated tissue by weight.

${ }^{\mathrm{y}}$ Rated based on the 0 to 5 scale where $0=$ no deteriorated pieces and $5=$ severely deteriorated pieces.

${ }^{\mathrm{x}}$ Means followed by different letters are significantly different at $P<0.05$.

indicated that the phenotypes observed in the CA chambers for most, but not all, of the tested cultivars were probably not from low $\mathrm{O}_{2}$ damage or $\mathrm{CO}_{2}$ injury as it is described in the literature. As an exception to this trend, we observed that the performance of 'Triple Threat' and 'La Brillante' was better in the CA chamber test compared with the MA bag test. The accumulation and sensitivity to $\mathrm{CO}_{2}$ may explain the increased damage of 'Triple Threat' and 'La Brillante' in MA bags, although we cannot exclude the possibility that this resulted from evaluating the CA chamber test $7 \mathrm{~d}$ sooner than the MA bags. In CA chambers, the atmosphere is continually replenished with a consistent ratio of $\mathrm{O}_{2}$ and $\mathrm{N}_{2}$ and any potentially harmful gases such as $\mathrm{CO}_{2}$ are removed. Therefore, cultivars that are sensitive to $\mathrm{CO}_{2}$ may perform better in CA chambers.

Because of the rapid increase in lettuce produced for minimal processing into salad-cut products, it is critical that newly developed cultivars possess characters needed to maintain high quality in MA environments. We have developed two methods to assess shelf life in these conditions, one using MA bags and another using CA chambers. The results from using these two methods were correlated, and therefore, both methods could be used to select among lettuce lines for their shelf life in MA environments. Both methods have their advantages and disadvantages. MA bags directly test lettuce germplasm in the manner that they will be used. Although the use of MA bags introduces the complexity of matching packaging film oxygen transmission rating, product respiration, and the composition of the initial gas flush, Heimdal et al. (1995) reported that three butterhead cultivars had parallel responses to three different packaging schemes. Regardless, it seems plausible that the complexities of MA bags could introduce variability into multi-year and location evaluations of diverse germplasm. CA chambers reduce some of these complexities, but may not expose variation that is unique to MA bags. Regardless, breeders can use these methods to characterize or identify breeding lines that are suitable for salad-cut markets before release, and to select for increased shelf life within breeding populations. These practices should facilitate a consistent release of germplasm with high quality in MA environments.

\section{Literature Cited}

Bolin, H.R. and C.C. Huxsoll. 1991. Effect of preparation procedures and storage parameters on quality retention of salad-cut lettuce. J. Food Sci. 56:60-67.

Chiesa, A., D. Frezza, A. Fraschina, G. Trincheros, S. Moccia, and A. León. 2003. Pre-harvest factors and fresh-cut vegetable quality. Acta Hort. 604:153-159.

Couture, R., M.I. Cantwell, D. Ke, and M.E. Saltveit, Jr. 1993. Physiological attributes related to quality attributes and storage life of minimally processed lettuce. HortScience 28:723-725.

Glaser, L.K., G.D. Thompson, and C.R. Handy. 2001. Recent changes in marketing and trade practices in the U.S. lettuce and fresh-cut vegetables industries. Agr. Info. Bull. No. 767.

Hayes, R.J., G.E. Vallad, Q.-M. Qin, R.C. Grube, and K.V. Subbarao. 2007. Variation for resistance to verticillium wilt in lettuce (Lactuca sativa L.). Plant Dis. 91:439-445.

Heimdal, H., B.K. Kühn, L. Poll, and L.M. Larson. 1995. Biochemical changes and sensory quality of shredded and MA-packaged iceberg lettuce. J. Food Sci. 60:1265-1276.

Kim, J.G., Y. Luo, Y. Tao, R.A. Saftner, and K.C. Gross. 2005. Effect of initial oxygen concentration and film oxygen transmission rate on the quality of fresh-cut romaine lettuce. J. Sci. Food Agr. 85:1622-1630. 
Lopez-Galvez, G., M. Saltveit, and M. Cantwell. 1996. The visual quality of minimally processed lettuces stored in air or controlled atmospheres with emphasis on romaine and iceberg types. Postharvest Biol. Technol. 8:179-190.

Mateos, M., D. Ke, M. Cantwell, and A. Kader. 1993. Phenolic metabolism and ethanolic fermentation of intact and cut lettuce exposed to $\mathrm{CO}_{2}$-enriched atmospheres. Postharvest Biol. Technol. $3: 225-233$.
Smyth, A.B., J. Sung, and A. Cameron. 1998. Modified-atmosphere packaged cut iceberg lettuce: Effect of temperature and $\mathrm{O}_{2}$ partial pressure on respiration and quality. J. Agr. Food Chem. 46:4556-4562.

Varoquaux, P., J. Mazollier, and G. Albagnac. 1996. The influence of raw material characteristics on the storage life of fresh-cut butterhead lettuce. Postharvest Biol. Technol. 9:127-139.

Watada, A. and L. Qi. 1999. Quality control of minimally processed vegetables. Acta Hort. 483:209-219. 